This is the accepted version of the article:

Simmchen, J.; Baeza, A.; Ruiz-Molina, D.; Vallet-Regí, M. . Improving catalase-based propelled motor endurance by enzyme encapsulation. Nanoscale, (2014). 6. 15: 8907 10.1039/c4nr02459a.

Available at: https://dx.doi.org/10.1039/c4nr02459a 


\title{
Improving catalase-based propelled motors endurance by enzyme encapsulation
}

\author{
Juliane Simmchen $^{a, b}$, Alejandro Baeza*c, ${ }^{*,}$ Daniel Ruiz-Molina ${ }^{a, b}$ and Maria Vallet- \\ Regi ${ }^{c, d}$
}

\begin{abstract}
Biocatalytic propulsion is expected to play an important role in the future of micromotors as it might drastically increase the number of available fuelling reactions. Though, most of the enzymepropelled micromotors so far reported still rely on the degradation of peroxide by catalase, in spite being vulnerable to relatively high peroxide concentrations. To overcome this limitation herein we present a strategy to encapsulate the catalase and to graft those enzyme capsules on motor particles. Significant improvement of the stability in the presence of peroxide and other aggressive agents has been observed.
\end{abstract}

\section{Introduction}

The Whitesides research group pioneered the use of a Platinum layer to decompose hydrogen peroxide and generate autonomous movement in $2002 .{ }^{1}$ Since then, the fabrication of novel and more efficient nano- and micromotors has rapidly turned into a growing field of research. Diverse mechanisms to transform energy into movement as: i) water decomposition by an $\mathrm{Al}-\mathrm{Ga}$ alloy, ${ }^{2}$ ii) use of hybrid systems containing living organism for propulsion, ${ }^{3,4}$ and iii) fuel free approaches as UV light-induced molecular movement, ${ }^{5-7}$ electric fields, ${ }^{8,9}$ magnetic fields ${ }^{10-14}$ or ultra sounds, ${ }^{15,16}$ have been explored. Most of the examples so far reported are based on Platinum, ${ }^{17-21}$ which mimics the function of the biological enzyme catalase. However, its catalytic activities is not reaction-specific, one of the reasons that explains its rapid passivation ${ }^{22}$ while favouring side reactions. As the nano-/micromotors field is moving towards real life applications overcoming such limitations represents a challenge. Therefore the use of enzymes represents a promising alternative. The highly specific reactions catalyzed by enzymes avoid side reactions and undesired side products. Another advantage is that no heavy metals as $\mathrm{Pt}$ or $\mathrm{Mn}$ need to be discharged or recovered after their use, making the use of enzymes not only cheaper but also environmentally friendly. Moreover, due to the high flexibility of enzymes - over 4000 biochemical reactions are known to be enzyme catalysed- highly specific biocatalytic self-propelled movement could be induced in the near future. First successful approaches to integrate enzyme-catalyzed motors have already been done. Recently Sanchez et al. presented a tubular motor based on catalase immobilization, the same enzyme that has been used in our group for the propulsion of an asymmetric hybrid motor. ${ }^{23,24}$ Carbon nanotubes movement induced by enzyme tandems consuming biocompatible glucose fuel have been shown by Feringa et $a l^{25}$ Moreover, Mano and Heller demonstrated rapid propulsion of electron conducting carbon fibers containing a redox-polymer wired glucose oxidase and an oxygen-reducing bilirubin oxidase. ${ }^{26}$

The main limitation for the application of enzymes is their immobilization. Even though several techniques for enzyme immobilizations are available ${ }^{27,28}$ chemical treatment is expected to damage it and consequently decrease their activity. To overcome this problem, we were inspired by a recently reported work of $\mathrm{Lu}$ and coworkers, who improved the enzyme performance upon encapsulation. ${ }^{29}$ This method has been extended to several proteins, as for example enhanced green fluorescent protein, bovine serum albumin, superoxide dismutase and caspase- $3 .{ }^{30-32}$ Herein we apply the concept of enzyme encapsulation by a polymeric shell with the aim to improve the performance of biocatalytic micromotors (Fig. 1). For this, a modification of the methodology described by $\mathrm{Lu}$ is applied consisting on the introduction of amino groups on the capsule by proper selection of the monomer reactants. Such groups allow grafting of the encapsulated enzyme on the swimmers surface while favouring their stability.

\section{Experimental section}

Catalase was bought in Aldrich as a lyophilized powder. Commercially available enzymes mostly contain $\left(\mathrm{NH}_{4}\right)_{2} \mathrm{SO}_{4}$ and 


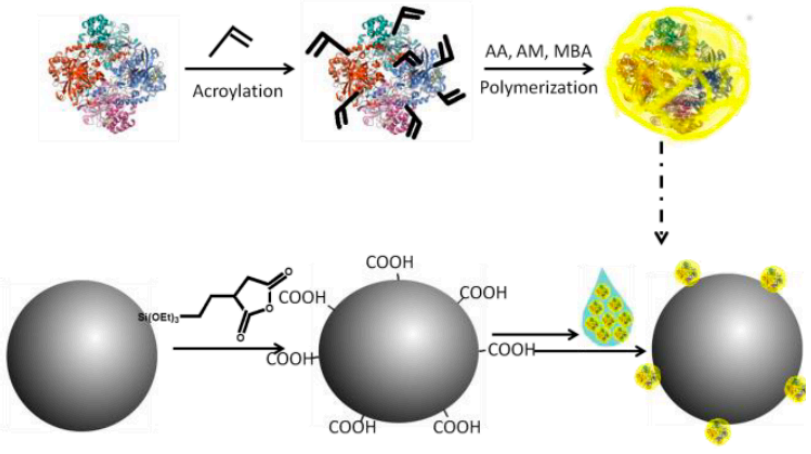

Fig.1.Schematic principle of enzyme encapsulation and covalent grafting of the capsules on the silica surface (AA -acrylamide, AM hydrochlorid salt of 2-aminoethylmethacrylate, MBA - N,N'methylene bisacrylamide)

smaller protein fragments. Therefore a purification step previous to use is recommendable. Thus, the enzymes were purified following a previously described method ${ }^{32}$ which briefly consist on the filtration of the commercial enzymes dissolved in $0.01 \mathrm{M}$ sodium carbonate buffer $\mathrm{pH} 8.5$ through Amicon filters. This way, the removal of smaller protein fragments, ammonium sulfate and chemical impurities are achieved.

Using a BCA assay the recovered protein after filtration was quantified to be around $63 \%$ using $100 \mathrm{kDa}$ filter and $93 \%$ using a $10 \mathrm{kDa}$ filter. In order to maintain more defined conditions in the polymerization the $10 \mathrm{kDa}$ filter was defined as a standard prepurification step. After this purification step only a slight lose in catalytic activity lower than $5 \%$ was documented (Fig ESI 1). The washing solution showed some remaining activity, which was insignificant compared to the remaining protein. Therefore it can be assumed that the mayor part of smaller protein fragments are not catalytically active and can be removed without losing significant catalytic activity.

Acroylation. Approx. $5 \mathrm{mg}$ of purified enzyme were dissolved in 1 $\mathrm{ml}, 0.01 \mathrm{M}$ sodium carbonate buffer $(\mathrm{pH} 8.5)$ and reacted with a 20 fold excess of $N$-acryloxysuccinimide, dissolved in $10 \mu \mathrm{l}$ DMSO during $30 \mathrm{~min}$ at room temperature. Finally, the reaction solution was filtered through Amicon filters of $50 \mathrm{kDa}$ and collected in $100 \mu \mathrm{l}$ $0.01 \mathrm{M}$ sodium carbonate buffer $(\mathrm{pH} 8.5)$. The modification was monitored by DLS and Zetapotential, as well as the protein content and the relative amino-content is compared.

Polymerization on acroylgroups. Diluting the acryloylated enzyme in $1000 \mu \mathrm{l} 0.01 \mathrm{M}$ deoxygenated sodium carbonate buffer $(\mathrm{pH} 8.5)$, radical polymerization was performed. A ratio of 450-9000 eq. monomer/enzyme,aminoethyl methacrylate (positively charged monomer), 1200-12000 eq. acrylamide (neutral monomer) and 502000 eq. $N, N^{\prime}$-methylene bisacrylamide as crosslinker were added in $2 \mathrm{ml} 0.01 \mathrm{M}$ phosphate buffer (PB) $(\mathrm{pH}$ 7.4). The polymerization was initiated by adding 500 eq of ammonium persulphate and 1000 eq. $N, N, N^{\prime}, N^{\prime}$-tetramethylethylenediamine dissolved in $1 \mathrm{ml}$ deoxygenated PB buffer into the reaction media. The mixture was allowed to react at room temperature during $90 \mathrm{~min}$ in nitrogen atmosphere. Unreacted monomers and initiators were removed by filtration and subsequent washing steps applying Amiconfilters $50 \mathrm{KDa}$. The success of capsule formation was monitored by DLS where an increase in size from $7,2 \mathrm{~nm}$ (native catalase) to a range from 9.5 up to $60 \mathrm{~nm}$ for encapsulated enzyme was observed. These results were confirmed by TEM using phosphotungstic acid as staining agent in order to visualize properly the enzyme-polymer capsules. Zeta potential measurements did not show significative changes. In order to confirm the presence of aminogroups in the capsule the fluorescamine test was employed.

Enzymatic activity assay. The enzymatic activity was determined spectrophotometrically by using $\mathrm{H}_{2} \mathrm{O}_{2}$ as a substrate following a procedure published elsewhere ${ }^{33}$. Briefly, $25 \mu \mathrm{L}$ of a solution of enzyme in $50 \mathrm{mM} \mathrm{PB} \mathrm{pH} 7.0$ with a concentration of $1 \mathrm{mg} \mathrm{ml}^{-1}$ was added to $11 \mathrm{mM} \mathrm{H}_{2} \mathrm{O}_{2}$ in $50 \mathrm{mM} \mathrm{PB}$ solution with rapid stirring. The decrease in absorbance at $240 \mathrm{~nm}$ (with an extinction coefficient of $0.041 \mathrm{mmol}-1 \mathrm{~cm}-1$ ) was recorded after 30 seconds at $20{ }^{\circ} \mathrm{C}$. One unit of catalase will decompose $1 \mu \mathrm{mol}$ of $\mathrm{H}_{2} \mathrm{O}_{2}$ per minute at $\mathrm{pH} 7.0$ and $20{ }^{\circ} \mathrm{C}$. The enzymatic activity was expressed in Units per milligram of dry solid.

\section{Enzymatic stability evaluation.}

Against enzymatic degradation by protease: $1 \mathrm{mg}$ of the catalase capsules or native catalase was placed on $1 \mathrm{~mL}$ of a solution of 5 $\mathrm{mg} \cdot \mathrm{ml}-1$ of protease in $\mathrm{PB} 0.1 \mathrm{M}(\mathrm{pH}$ 7.2). The mixture was incubated during $2 \mathrm{~h}$ at $37{ }^{\circ} \mathrm{C}$ and $100 \mathrm{rpm}$. After this time, the mixture was placed in a dialysis sack of Pure-A-Lyzer ${ }^{\mathrm{TM}}$ immersed in $8 \mathrm{~mL}$ of $\mathrm{H}_{2} \mathrm{O}_{2} \quad 1.5 \%$. The amount of $\mathrm{H}_{2} \mathrm{O}_{2}$ was determined by $\mathrm{UV}$ absorption at $240 \mathrm{~nm}$ after $30 \mathrm{~min}$.

Temperature stability: $50 \mu \mathrm{l}$ of encapsulated or native enzymes solution in PBS $0.1 \mathrm{M}(\mathrm{pH} 7.2)$ were added to $450 \mu \mathrm{L}$ of the same buffer. Then, the solution was exposed to high temperature $\left(60^{\circ} \mathrm{C}\right.$ during $1 \mathrm{~h}$ ) under constant shaking and protected from light. After this time, the enzymatic activity of the enzymes was determined following the degradation of $\mathrm{H}_{2} \mathrm{O}_{2}$ by UV-absorption at $240 \mathrm{~nm}$.

Surface modification of silica particles. $40 \mathrm{mg}$ of commercial Silica particles of approx. $10 \mu \mathrm{m}$ were dried during $2 \mathrm{~h}$ at $80^{\circ} \mathrm{C} .5 \mathrm{ml}$ of dry toluene and a 5-fold (10mg) excess of (3-succinimylpropyl)triethoxysilane regarding to silanol groups on the particle surface were added and reacted overnight. $1 \mathrm{~nm}^{2}$ silica bears approximately 4.9 OH-groups. ${ }^{34,}{ }^{35}$. After the reaction time, particles were washed with toluene and $\mathrm{EtOH}$ and dried subsequently.

Enzyme anchoring on silica particles. $2 \mathrm{mg}$ particles were dispersed in $0.1 \mathrm{M} \quad \mathrm{PB}$ with $1 \mathrm{mg} \quad N$-(3-dimethylaminopropyl)- $\mathrm{N}^{\prime}-$ ethylcarbodiimide hydrochloride (EDC) and $2 \mathrm{mg} \mathrm{N}$ hydroxisuccinimide (NHS) in order to activate $\mathrm{COOH}$ groups. After $30 \mathrm{~min}$ of stirring, $3 \mathrm{mg}$ of native or encapsulated catalase respectively were added. Further stirring during $2 \mathrm{~h}$ at room temperature let to covalent immobilization of the enzyme on the particle surface. After this time, the particles were extensively washed with $0.1 \mathrm{M}$ PB in order to remove the physically absorbed proteins. The whole process was monitored by FTIR spectroscopy. (see Fig. 3a) and other analytical techniques such as TGA (see Fig. $3 b)$, elemental analysis and amino assay as shown in table 2

Turn over evaluation of enzyme-silica motors. $1 \mathrm{mg}$ of particles bearing the native or encapsuled catalase respectively were suspended in $0.2 \mathrm{~mL}$ of $\mathrm{PB} 0.1 \mathrm{M} \mathrm{pH} 7.2$, placed on the membrane of a Corning ${ }^{\circledR}$ Transwell ${ }^{\circledR}$ with $0.4 \mu \mathrm{m}$ of pore and immersed in 1.5 $\mathrm{mL}$ of a solution of $1.5 \%$ of $\mathrm{H}_{2} \mathrm{O}_{2}$. After $30 \mathrm{~min}$, the amount of $\mathrm{H}_{2} \mathrm{O}_{2}$ was determined by UV-absorption at $240 \mathrm{~nm}$. Then, the liquid was 
removed and replaced by $1.5 \mathrm{~mL}$ of fresh $\mathrm{H}_{2} \mathrm{O}_{2} \quad 1.5 \%$ and the procedure was repeated ten times.

Enzyme anchoring on aminated Polystyrene particles. $10 \mu \mathrm{l}$ of a commercial amine-modified polystyrene fluorescent blue beads aqueous solution $2.5 \%$ was diluted in $0.5 \mathrm{~mL}$ PB $0.1 \mathrm{M} \mathrm{pH} 7.2$. Then, $0.5 \mathrm{mg}$ of Suberic acid bis( $N$-hydroxysuccinimide ester) (DSS) as crosslinker solved in $10 \mu \mathrm{L}$ of DMSO was added. After $30 \mathrm{~min}$ of stirring, $1 \mathrm{mg}$ of native or encapsulated catalase was added. Further stirring at room temperature overnight let to covalently anchored encapsulated enzyme on the particle surface, while the grafting of native catalase was only successful to a very low extend.

Motion evaluation. The evaluation of the capacity to perform motion was performed on microscopy glass slides placed in a 6 well plate. Motor particles were placed in distilled water containing $2.5 \%$ of $\mathrm{H}_{2} \mathrm{O}_{2}$ and $10 \%$ glycerine to diminish media movement, to which $1 \mu \mathrm{l}$ particles dispersed in distilled water were added. The movement was observed in an EVOS xl digital inverted microscope and videos were recorded with a EASTMAN KODAK EASYSHARE Z1015 IS digital camera at 29,97 fps. Obtained videos are available in the supporting information.

\section{Results and discussion}

Enzyme encapsulation. The first step for the enzyme encapsulation is the introduction of polymerizable groups on the enzyme surface. This reaction was performed using acrylic acid $\mathrm{N}$ hydroxysuccinimide ester in $\mathrm{pH} 8.5 \mathrm{Na}_{2} \mathrm{CO}_{3} 50 \mathrm{mM}$ buffer, which reacts with the free amino groups present in the protein. After purification, radical polymerization was carried out using a mixture of acrylamide (AA) as neutral monomer, $N, N^{\prime}$-methylene bisacrylamide (MBA) as crosslinker and hydrochlorid salt of 2aminoethylmethacrylate (AM) as monomer responsible for the introduction of amino groups in the presence of APS/TMEDA. To optimize the capsule formation, the monomer ratio (AA:AM:MBA) was initially fixed to $6.0: 4.5: 1.0$ and different conditions varying the acrylamide:enzyme ratio between 1200:1 and 12000:1 were tested. Optimal conditions were found for low monomer contents (Table la, maintained and the effect of the modification of the monomercrosslinker relation was determined.

a)
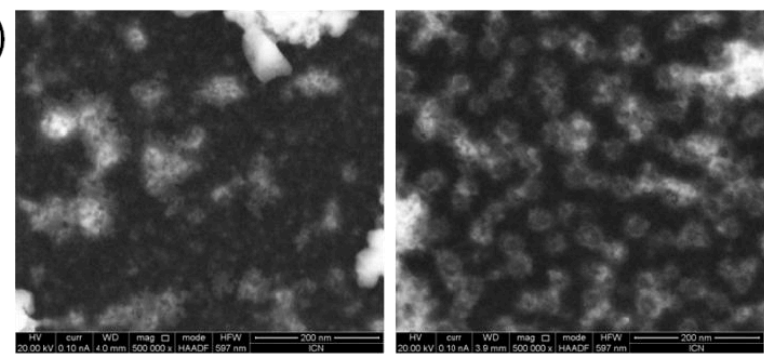

b)
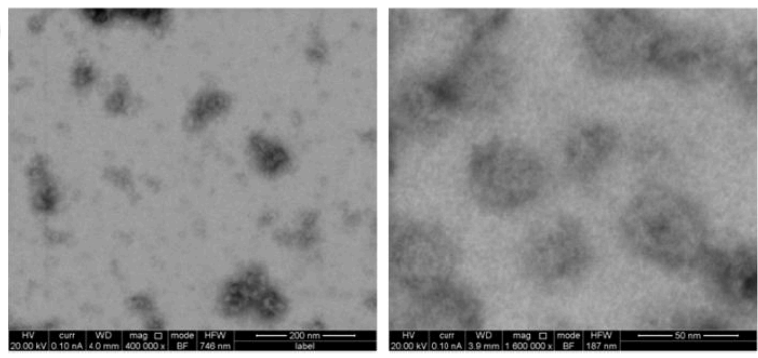

Fig. 2.a) Scanning transmission electron microscope (STEM) image in high angle annular dark field mode of native vs encapsulated enzyme solution. b): bright field STEM of native vs encapsulated enzyme solution magnification left: $400000 x$, right $1600000 x$. All samples were prepared by staining with $1 \%$ phosphotungstic acid.

A general trend that can be observed is a gelification process upon crosslinker increase, followed by entrapment of the enzyme capsules and low recovery ratio (Table 1a). Moreover, as expected, lower ratios of AM led to lower superficial amino contents. Interestingly, similar results are obtained upon increasing the crosslinker since it is capable to react with free amine-side chains in the polymer (Table 1b). Finally, optimal conditions for the fabrication of capsules with high recovery, defined size and high grade of accessible amino groups on the surface were those defined in entry d of Table 2 . Fabrication of capsules with average size of $30 \mathrm{~nm}$ was confirmed by TEM using phosphotungstic acid as staining agent (Fig. 2). The

Table 1. Evaluation of conditions for capsule synthesis (a) variation of the monomer/enzyme ratio. (b) variation of relations between the monomers maintaining fixed the monomer enzyme ratio. Optimal conditions were marked grey in both tables.

\begin{tabular}{|l|l|l|l|l|l|}
\hline Tablela & \multicolumn{3}{|l|}{ Monomer ratio } & \multicolumn{2}{l|}{ Capsules } \\
\hline Entry & AA & AM & MBA & $\begin{array}{l}\text { Recovered } \\
\text { Mass [mg] }\end{array}$ & $\begin{array}{l}\text { DLS } \\
{[\mathrm{nm}]}\end{array}$ \\
\hline a & 1200 & 900 & 200 & 3,71 & 9,57 \\
\hline b & 3000 & 2250 & 900 & $<1 \mathrm{mg}$ & 19,3 \\
\hline c & 6000 & 4500 & 1000 & $<1 \mathrm{mg}$ & 60,6 \\
\hline d & 12000 & 9000 & 2000 & Gel formation \\
\hline
\end{tabular}

entry a), as higher monomer content led to formation of bulk polymer. In the following, the optimal enzyme:AA ratio was

\begin{tabular}{|l|l|l|l|l|l|l|}
\hline Table1b & \multicolumn{5}{|l|}{ Monomer ratio } & \multicolumn{3}{l|}{ Capsules } \\
\hline Entry & AA & AM & MBA & $\begin{array}{l}\text { Recovered } \\
\text { Mass [mg] }\end{array}$ & $\begin{array}{l}\text { DLS } \\
{[\mathrm{nm}]}\end{array}$ & $\begin{array}{l}\mathrm{NH}_{2} \\
{[\%]^{*}}\end{array}$ \\
\hline a & 1200 & 900 & 200 & 3,71 & 9,57 & 87,5 \\
\hline b & 1200 & 450 & 200 & 2,55 & 9,93 & 65,6 \\
\hline c & 1200 & 900 & 300 & $<1 \mathrm{mg}$ & 64,6 & $\times$ \\
\hline d & 1200 & 900 & 100 & 3,77 & 14,2 & 175 \\
\hline
\end{tabular}

existence of superficial amino-groups has been proven by a fluorescamine assay; overall capsules present approximately $75 \%$ more accessible amino-groups than native catalase. 
The enzymatic activity of each step was spectrophotometrically measured following the decomposition of $\mathrm{H}_{2} \mathrm{O}_{2}$ at $240 \mathrm{~nm} .{ }^{33}$ The acroylation step scarcely modified the activity retaining more than $95 \%$ of the activity. The encapsulated enzymes obtained after the polymerization process lost almost $50 \%$ of the initial activity (Fig ESI 1). The enzymatic activity was expressed in Units per mg of dry solid residue. Obviously, the presence of the polymer coat increases the weight of the enzyme in a proportion difficult to determine with precision and this fact is the main reason for this activity lost. Other reasons that can diminish the activity of the encapsulated enzyme can be active site blockage and lower peroxide diffusion into the polymer shell. Despite the decrease in the activity, the enzyme still retains around $50 \%$ of the initial activity after the acroylation and polymerization processes while exhibit a significant increase in its thermal stability and resistance to protease degradation. After 1 hour at $60{ }^{\circ} \mathrm{C}$, the enzyme capsules retain more than $50 \%$ of their initial activity whereas the native enzyme loses almost $80 \%$ of its activity. (Fig. ESI 2)
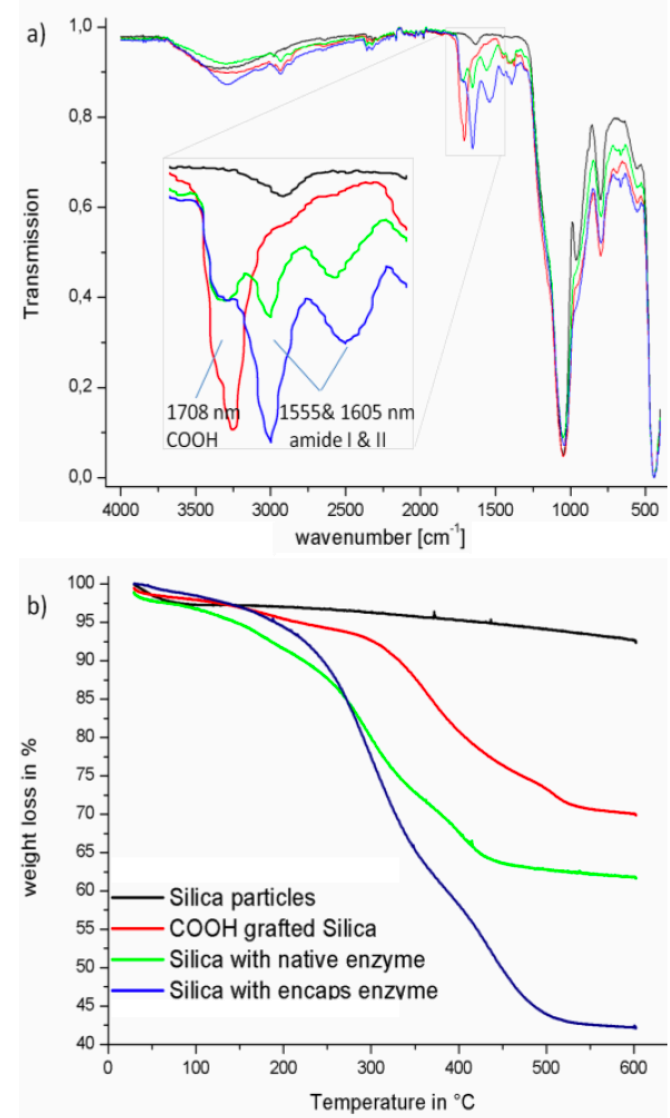

Fig. 3. a) Surface functionalization of Silica particles monitored by FTIR, where typical bands for grafted $\mathrm{COOH}$ groups and amide groups from the enzyme binding can be observed. b) Thermogravimetric analysis of each step of the process.

The stability of the capsules against enzymatic degradation was also tested incubating them in a solution of $5 \mathrm{mg} \mathrm{mL}^{-1}$ of protease at 37 ${ }^{\circ} \mathrm{C}$ during $2 \mathrm{~h}$. After this time, the remaining activity was evaluated following the decomposition of $\mathrm{H}_{2} \mathrm{O}_{2}$ as in the previous cases. The encapsulated enzyme retains more than $90 \%$ of its initial activity whereas the native enzyme completely loses its activity. These results are of great relevance for potential applications of these motors in biological fluids where proteolytic enzymes can be present.

Silica functionalization and enzyme attachment. Carboxylic groups are introduced in the silica surface upon reaction with (3succinimylpropyl)-triethoxysilane in toluene at $80^{\circ} \mathrm{C}$ under nitrogen atmosphere. Once functionalized, the enzymatic capsules were covalently attached by coupling with EDC and NHS. The whole process was followed by FTIR; I) initially the spectrum is typical for naked silica (Fig 3a), II) after $\mathrm{COOH}$-grafting $\mathrm{C}=\mathrm{O}$ band of the carboxylic group is clearly visible at $1708 \mathrm{~cm}^{-1}$ and III) during the conjugation with the enzyme capsules this band suffer a strong intensity decrease. This last observation also confirms that the enzymes are covalently bond and not only physically absorbed. Enzyme attachment was also confirmed by thermogravimetric (TGA) and elemental analysis. As can observed in Figure 3b, $\mathrm{COOH}$ grafted silica particles exhibit a gradual mass decrease up to $22 \%$ in weight upon increase of the temperature. By comparison with the same temperature behaviour of bare silica particles, the weight loss has been tentatively attributed to the surface $\mathrm{COOH}$ groups. This value is considerably higher than that expected for a monolayer of carboxylgroups (approx. 6,5 wt\%) and therefore, it can indicate that polycondensation is taking place. The higher amount of carboxylic groups on the surface could facilitate even more the enzyme attachment. According with the TGA experiments (Fig. 3b), the amount of native enzyme bounded to the silica surface was $8 \%$, whereas the encapsulated catalase reached $25 \%$. The higher grafting amount for the encapsulated enzyme may account for: I) the polymer capsules increase the average weight of each enzyme unit and/or II) the capsules present a higher number of amino groups on their surface compared to the native catalase. Amino assay through flourescence measurement after reaction with fluorescamine resulted in an approximately $75 \%$ higher amine content in the polymer shell than in the native catalase. The grafting reaction activated by EDC/NHS benefits from those aminogroups and the protein grafting is more efficient. The higher amount of protein bounded to the silica surface was confirmed by S-selective elemental analysis, which is completely selective to the enzyme, as neither the silica particles nor the methacrylate capsules contain Sulfur. The S-content in a sample of particles bearing encapsulated enzyme was approx. 5 times higher than in particles with native enzyme on their surface.

Finally, stability experiments of the catalase enzyme against the oxidation by the peroxide were done. Even though this enzyme contains a NADH factor in each subunit to protect itself from oxidation, it is well known that exposure to peroxide is critical for the enzyme stability, being rapidly deactivated. In order to study the stability of the attached enzymes against oxidation in the presence of hydrogen peroxide, the enzymatic activity of silica particles bearing native or encapsulated catalase respectively on their surface was determined after several work cycles exposing the particles to a fresh $\mathrm{H}_{2} \mathrm{O}_{2}$ solution each half hour. As it can be observed in Figure 4, silica particles conjugated with encapsulated catalase are able decompose practically the same amount of hydrogen peroxide during more than 10 cycles losing only less than $40 \%$ of their initial activity at the end of the whole process. The silica particles covered by 
native enzymes show a significant activity decrease after only 2 or 3 cycles.
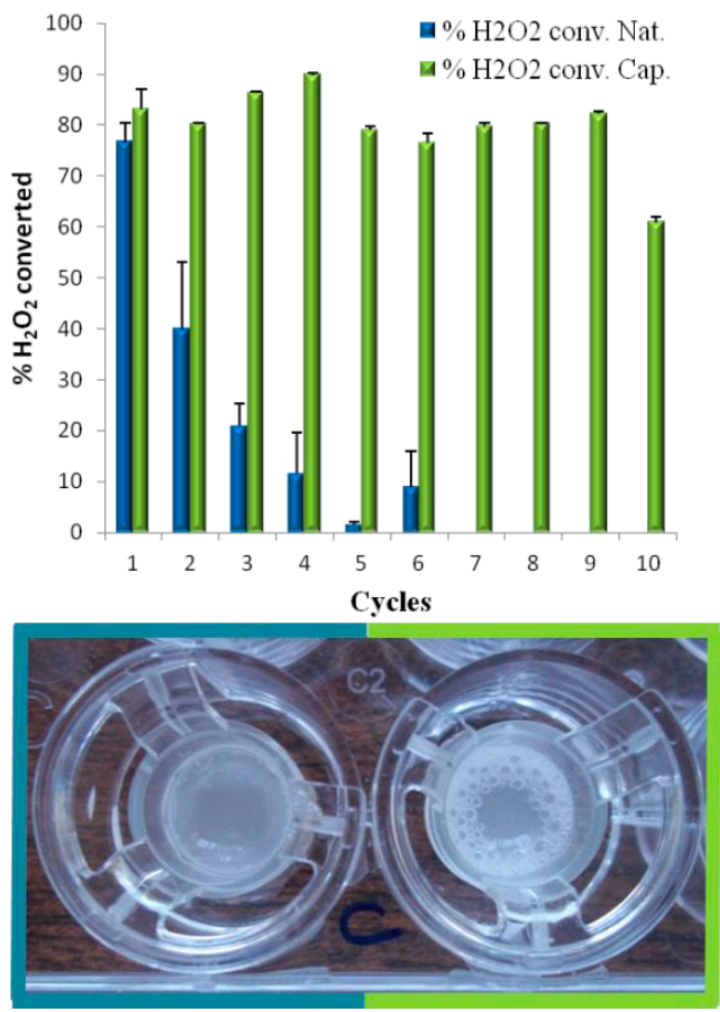

Fig. 4. Top: $\% \mathrm{H}_{2} \mathrm{O}_{2}$ conversion by native enzyme vs encapsulated enzyme grafted on Silica particles. Bottom: Images taken after 10 cycles, left well correspond to native catalasesilica particles and right well to encapsulated enzyme-silica particles.

Motion experiments. The silica-enzyme particles was placed in a $2,5 \%$ peroxide solution whereupon immediate bubble production at the surface of the microparticlesis visible. Fast bubble production leads to a "jet propulsion" behaviour, i.e. the fast generation of bubbles propel the movement. As a representative example Fig. 5a-b shows a circular trajectory of silica microparticles (Videos 1, and 2 ESI shows more examples of particle motion).No further mechanisms beyond bubble formation were detected in spite most particle shaped motors are also strongly influenced by gradient driven factors (by comparison with other systems as tube-shaped motors that favour bubble driven mechanisms). ${ }^{17,} 21$ This fact has been tentatively attributed to the high reaction rates of our enzyme that leads to strong accumulation of oxygen bubbles. These results are similar to those already reported by $\mathrm{us}^{23}$ and by Gibbs and Zhao. ${ }^{36}$

Beyond the self-propelled movement, a remarkable stability enhancement is achieved upon encapsulation. Movement is ceased for native catalase after a short period of time as the enzyme gets oxidized by the fuel. On the contrary, in our experiments stalling takes far longer (depending on experimental conditions in the range of $30 \mathrm{~min}$ ) and is reversible by adding more peroxide fuel. This indicates that the stalling is not due to degradation of the enzyme but caused by the consumption of the fuel. ${ }^{22}$

Finally, to demonstrate that amino coupling is not limited to carboxyl groups and/or silica particles or to discard nonspecific linkage through hydrogen bonding, we coupled these encapsulated enzymes to fluorescent polystyrene (PS) particles which bear surface amino groups. For this, we used a Suberic acid bis( $N$-hydroxysuccinimide ester) crosslinker (DSS), able to connect via covalent bond formation amino to amino groups. ${ }^{28}$ In this case, the enzymatic activity of the resulting particles was very low and difficult to measure with enough precision. However, the movement could be mainly observed in particle agglomerations (Fig 5c-d), which might be due to several factors. In the first instance due to the particle size of $1 \mu \mathrm{m}$ the observation of single particles is more difficult, so bigger agglomerates easier catch the attention of the experimenter. On the other hand the anchoring of enzymes might be more favoured in agglomerations due to increased van der Waals forces. Bubble formation by catalase between fluorescent particles can be seen in video 3 ESI. Analogous observations as in silica motors confirm that the movement last longer and after stalling the movement could be reactivated by addition of new fuel.
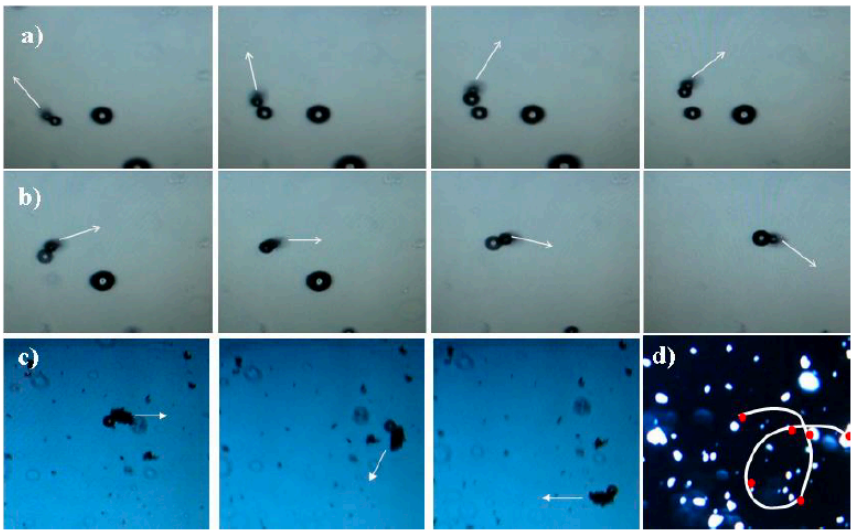

Fig. 5 a-b) Sequence of pictures showing a circular movement of a Silica motor caused by jet-propulsion mechanism. c) Sequence of pictures showing a circular movement of a PS particles motor and d) Trajectory followed by PS aggregate by fluorescence microscopy.

\section{Conclusions}

In this paper we present a method to encapsulate catalase in a novel polymer shell bearing amine groups which allows further attachment on different surfaces. The enzyme-capsules were characterized regarding their appearance, surface properties and their catalytic efficacy. Afterwards, a proper methodology for their grafting on motor particles was established and the improved performance of those motors evaluated. We found that the durability of our micromotors bearing enzyme capsules was manifold increased compared to motors with native enzyme. The reusability of both types was compared and the capsules were more stable after thermal 
and enzymatic treatment, as well as in peroxide rich environment. Concluding, we can say that encapsulation of catalase strongly improved the resistance and reusability of catalase based micromotors. This result could pave the way to employ other enzymes, making accessible the use of other biologically relevant fuels.

\section{Acknowledgements}

J.S. thanks the CSIC (Spain) for its predoctoral grant. This work was supported by the Ministerio de Economía y Competitividad through Spanish CICYT through project MAT-2008-00736, MAT201238318-C03-02, MAT2012-35556 and Spanish National CAM through project S2009/MAT-172.

\section{Notes and references}

${ }^{a}$ ICN2 - InstitutCatala de Nanociencia i Nanotecnologia, Campus UAB, 08193 Bellaterra (Barcelona), Spain CSIC Staff.

${ }^{b}$ CSIC-Consejo Superior de Investigaciones Cientificas, ICN2 BuildingCampus UAB, 08193 Bellaterra (Barcelona), Spain

${ }^{\circ}$ Dep. de Química Inorgánica y Bioinorgánica, UCM, Plaza Ramón y Cajal $s / n$, Madrid, Spain,

${ }^{d}$ Center on Bioengineering, Biomaterials and Nanomedicine (CIBER-BBN), Spain

1. R. F. Ismagilov, A. Schwartz, N. Bowden and G. M. Whitesides, Angew. Chem Int. Ed., 2002, 41, 652-654.

2. W. Gao, A. Pei and J. Wang, ACS Nano, 2012, 6, 8432-8438.

3. D. B. Weibel, P. Garstecki, D. Ryan, W. R. DiLuzio, M. Mayer, J. E. Seto and G. M. Whitesides, PNAS, 2005, 102, 1196311967.

4. V. Magdanz, S. Sanchez and O. G. Schmidt, Advanced Materials, 2013, DOI: 10.1002/adma.201302544, n/a-n/a.

5. M. K. J. t. W. Richard A. van Delden, Michael M. Pollard, Javier Vicario, Nagatoshi Koumura, Ben Feringa, Nature, 2005, 437, 1337-1340.

6. M. M. P. Rienk Eelkema, N. K. Javier Vicario, Blanca, C. W. M. B. Serrano Ramon and B. L. F. Dirk J. Broer, Nature, 2006, $440,163$.

7. R. A. van Delden, N. Koumura, N. Harada and B. L. Feringa, Proceedings of the National Academy of Sciences, 2002, 99, 4945-4949.

8. A. K. Gabriel Loget, Nature Communications, 2011, 535.

9. S. T. Chang, V. N. Paunov, D. N. Petsev and O. D. Velev, Nature Materials, 2007, 6, 235-240.

10. J. B. Remi Dreyfus, Marcus L Roper, Marc Fermigier, Howard A. Stone, Jerome Bibette, Nature 2005, 437, 862-865.

11. B. Nelson, I. Kaliakatsos and J. Abbott, Annu. Rev. Biomed. Eng., 2010, 12, 55-85.

12. A. Ghosh and P. Fischer, Nano Letters, 2009, 9, 2243-2245.

13. L. Zhang, J. J. Abbott, L. Dong, K. E. Peyer, B. E. Kratochvil, H. Zhang, C. Bergeles and B. J. Nelson, Nano Letters, 2009, 9, 3663-3667.
14. W. Gao, S. Sattayasamitsathit, K. M. Manesh, D. Weihs and J. Wang, Journal of the American Chemical Society, 2010, 132, 14403-14405.

15. W. Wang, L. A. Castro, M. Hoyos and T. E. Mallouk, ACS Nano, 2012, 6, 6122-6132.

16. V. Garcia-Gradilla, J. Orozco, S. Sattayasamitsathit, F. Soto, F. Kuralay, A. Pourazary, A. Katzenberg, W. Gao, Y. Shen and J. Wang, ACS Nano, 2013, 7, 9232-9240.

17. L. Baraban, D. Makarov, R. Streubel, I. Mönch, D. Grimm, S. Sanchez and O. G. Schmidt, ACS Nano, 2012, 6, 3383-3389.

18. A. A. Solovev, S. Sanchez, M. Pumera, Y. F. Mei and O. G. Schmidt, Advanced Functional Materials, 2010, 20, 24302435.

19. M. Guix, J. Orozco, M. García, W. Gao, S. Sattayasamitsathit, A. Merkoçi, A. Escarpa and J. Wang, ACS Nano, 2012, 6, 44454451.

20. K. M. Manesh, M. Cardona, R. Yuan, M. Clark, D. Kagan, S. Balasubramanian and J. Wang, ACS Nano, 2010, 4, 17991804.

21. J. R. Howse, R. A. L. Jones, A. J. Ryan, T. Gough, R. Vafabakhsh and R. Golestanian, Physical Review Letters, 2007, 99, 048102.

22. G. Zhao, S. Sanchez, O. G. Schmidt and M. Pumera, Nanoscale, 2013, 5, 2909-2914.

23. J. Simmchen, A. Baeza, D. Ruiz, M. J. Esplandiu and M. ValletRegí, Small, 2012, 8, 2053-2059.

24. S. Sanchez, A. A. Solovev, Y. Mei and O. G. Schmidt, Journal of the American Chemical Society, 2010, 132, 13144-13145.

25. D. Pantarotto, W. R. Browne and B. L. Feringa, Chemical Communications, 2008, 1533-1535.

26. N. Mano and A. Heller, Journal of the American Chemical Society, 2005, 127, 11574-11575.

27. S. Datta, L. R. Christena, Y. Rani and S. Rajaram, 3. BIOTECH, 2013, DOI: 10.1007/s13205-012-0071-7, 1-9.

28. L. Cao, in Carrier-bound Immobilized Enzymes, Wiley-VCH Verlag $\mathrm{GmbH} \&$ Co. KGaA, 2006, DOI: 10.1002/3527607668.ch1, pp. 1-52.

29. M. Yan, J. Ge, Z. Liu and P. Ouyang, Journal of the American Chemical Society, 2006, 128, 11008-11009.

30. Z. Gu, M. Yan, B. Hu, K.-I. Joo, A. Biswas, Y. Huang, Y. Lu, P. Wang and Y. Tang, Nano Letters, 2009, 9, 4533-4538.

31. M. Yan, J. Du, Z. Gu, M. Liang, Y. Hu, W. Zhang, S. Priceman, L. Wu, Z. H. Zhou, Z. Liu, T. Segura, Y. Tang and Y. Lu, nature Nanotechnology, 2010, 5, 48-53.

32. Y. Liu, J. Du, M. Yan, M. Y. Lau, J. Hu, H. Han, O. O. Yang, S. Liang, W. Wei, H. Wang, J. Li, X. Zhu, L. Shi, W. Chen, C. Ji and Y. Lu, Nature Nanotechnology, 2013, 8, 187-192.

33. Y. Wang and F. Caruso, Chemistry of Materials, 2005, 17, 953961.

34. A. V. Kiselev, Kolloidn. Zhur., 1936, 2, 17.

35. L. T. Zhuravlev, Colloids and Surfaces A: Physicochemical and Engineering Aspects, 2000, 173, 1-38.

36. J. G. Gibbs and Y.-P. Zhao, Applied Physics Letters, 2009, 94, 163104. 